\title{
LAND USE ANALYSIS IN LATVIA IN THE CONTEXT OF SUSTAINABLE DEVELOPMENT
}

\author{
Linda KAUŠKALE ${ }^{1}$, Ineta GEIPELE ${ }^{2}$ \\ ${ }^{1,2}$ Riga Technical University, Latvia \\ Linda.Kauskale@rtu.lv
}

\begin{abstract}
The research focus is the examination of key aspects of the land use for the detection of urgent problems in the context of sustainable development. The comparison, data analysis and logical access methods have been used in the study, and the recommendations on the improvement of the situation in the longer term have been developed. Land use management, legal side of regulation and the efficiency of land use are essential guidelines for the sustainable development of the territory in the country.
\end{abstract}

Keywords: Land use, management, real estate market, sustainability.

\section{INTRODUCTION}

Land use issues are becoming more relevant not only in Europe but also in the whole world. The relevance of the study is determined by the fact that the efficiency of the land use, management and regulation basis also affects the country's socio-economic development.

The relevance of the research is defined by the fact that the land use, management and legal base of the regulation involves several phases and is not possible without a complex approach to this issue. All above-mentioned issues are of significant importance in the whole Europe and around the world. Non-efficient land use and management hamper the development of the territory and the country as a whole. At the same time, the country's socio-economic development affects the efficiency of the land use; hence, these parameters are interrelated.

The objective of the study is the examination of key aspects of the land use for the detection of urgent problems in the context of sustainable development and improvement of the situation. In the course of the study, the recommendations on the improvement of the situation in the longer term have been developed. The main tasks of the study are the following:

1. to perform the analysis of theoretical aspects of the issue, i.e. analysis of the scientific literature and other sources and the use of the other methods in the analysis of the current issues of the land use, including international experience;

2. to collect the quantitative data and perform the study;

3. to summarise the results of the research and develop the proposals on the improvement of the land use in the longer term.

A complex approach to the assessment of the land use allows defining and finding opportunities for the solution of a number of problematic issues. The comparison, data analysis and logical access methods have been used in the research. 


\section{THEORETICAL ASPECTS OF LAND USE AND ROLE OF LAND MANAGEMENT}

The land use in the country is affected by several factors. European continent is one of the most intensively used continents of the world, having the highest share of land used for production systems, settlement and infrastructure (European Environment Agency, 2013). Land and water resources are also the most important for societal development, as they are main agricultural production factors (Antonelli et al., 2015). According to the Food and Agriculture Organization of the United Nations (2015), land use information should provide answers to one or more of the following questions related to the current use of land:

- the purpose of activities undertaken (for example, the specific products and services that are sought);

- the geographic location and extent of the spatial unit under consideration;

- the temporal aspects of various activities undertaken (for example, the sequence of carried out operations like planning, weeding and others);

- the technologies employed (for example, technological input materials, such as fertilizer, irrigation, labour, etc.);

- quantitative measures (for example, areas, products);

- the reasons underlying the current land use (for example, land tenure, labour costs, market conditions, etc.).

Land use regulation is determined by a number of laws, rules of the Cabinet of Ministers of Latvia and other related documents. The belonging of the object to a particular real estate group is determined (State Land Service, 2015):

- for lands - by the objective of the use (Classification of the objectives of the use);

- for buildings (groups of premises) - by the method of the use (Classification of the buildings).

The belonging of the object to a particular group of real estate plays a key role in the cadastral evaluation because the use of the buildings is the basis for the determination of the objective of the land use.

Land use regulation is closely related to a land policy. Land policy is a national policy for land use and protection in order to ensure that the land is a sustainable use of the unique resource and the land policy has a number of sub-objectives (Ministry of Environmental Protection and Regional Development of the Republic of Latvia, 2015):

- to ensure the rational and efficient use of land under nature protection conditions;

- to establish an effective and stable legal, informational and economic environment in order to ensure the sustainable land use.

From a local government perspective, manifest economic interests stand in the way of the policy of reducing new land use, and these interests derive, which from the point of view of sustainability gives rise to the unfavourable situation (Fischer et al., 2013). 
Land use management is a complex process that consists of a number of activities. In the comparison of 12 Europe countries (Germany, Finland, Denmark, the Netherlands, France, Italy, Greece, Belgium/Flanders, the United Kingdom, the Czech Republic, Turkey and Poland), the most important challenges were defined (Getimis et al., 2014):

- the need for a better coordination with economic programming and sector policies;

- the need for simplification of the planning system: towards flexible planning;

- the prerogative of effectiveness and competitiveness;

- the upgrade of environmental concerns;

- the rise of "territorial governance".

To understand the consequences of landscape change, all decision makers must be provided with strong empirical evidence (Bertoloa et al., 2015). Planning reforms often attempt to introduce practices of innovative planning (Reimer et al., 2014). There are, however, considerable differences between the various member states, and especially between Western and Eastern Europe (Getimis et al., 2014).

Each European country has its own land management features, depending on the structure of the land use and a number of other factors. The primary types of the land cover in the European Union are presented in Fig. 1.

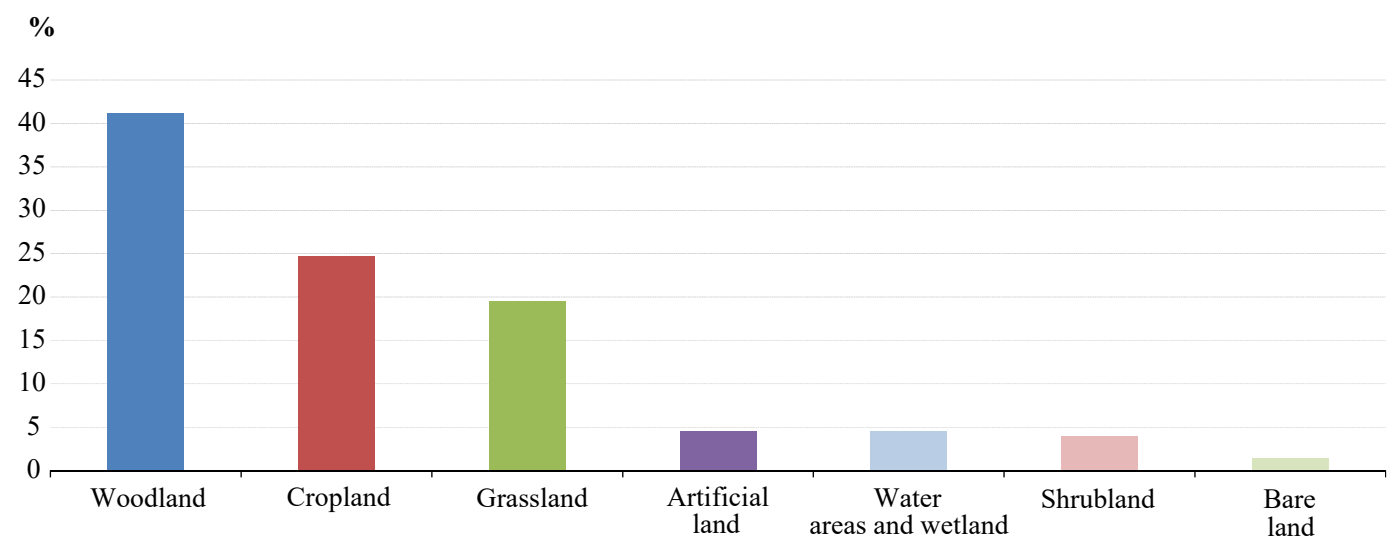

Fig. 1. Main land cover by land cover type, EU-27, 2012, $\%$ of total area (Eurostat, 2015).

Nowadays, there is a growing demand for an increase in agricultural output, but also environmental targets are expected to strengthen in the agricultural industry (O'Sullivan et al., 2015). It also follows from the definition of land management: "Land Management is the set of measures of the land policy implementation, the objective of which is to promote the sustainable land use and protection" (Legislation of the Republic of Latvia, Land Management Law, 2014).

The significant role of the land management belongs to the state and local municipalities. According to Chapter IV of the Land Management Law of Latvia, the state and local land management municipalities, the Cabinet of Ministers, the 
direct administration authorities and local authorities carry out the following functions (Legislation of the Republic of Latvia, Land Management Law, 2014):

(1) Cabinet of Ministers:

1) approves the state land policy;

2) issues regulations that provide the method to recover losses incurred in connection with the restrictions of the real estate rights, ensuring the access to inland public waters and special areas of conservation, the amount of compensation, calculation and payment procedures;

3) issues regulations that provide the method to recover losses incurred in connection with the restrictions of the business activities by defining the calculation and payment procedures of the amount of compensation for the planning of the local municipality territory, which is required for the development and construction of the public infrastructure;

4) issues regulations for the initiation of the land consolidation and financing procedure, for the land consolidation project content, design and implementation procedure, as well as for the procedure, which is defining the relative assessment of the land plots for the land consolidation needs;

5) issues regulations for the procedure of the registration and updating of the information on the coastal strip and inland public waters in the State Real Estate Cadastre Information System, and performs other functions.

(2) Direct administration authorities within their jurisdiction provide the land and soil protection measures by developing and implementing environmental protection, agriculture, fishery, forestry, transport and other policies.

(3) Local authorities are ensuring within their jurisdiction:

1) land monitoring in their administrative territories;

2) management of the reserve land fund.

The methods of improvement of the land management are becoming relevant.

Land use in future can be enhanced in several ways, for example, in France (Chakir and Gallo, 2013):

- first, land-use choice can be considered a dynamic process and should add another dimension to the information and provide more precise estimations;

- secondly, for land use modelling it is necessary to take into account time and space within a given framework.

Land management is of the key significance because it is closely related to the calculations of the cadastral value, and thus to the collected taxes. Therefore, data collection on the structures and all kinds of real estate and land is very important. Currently used construction data acquisition and updating methods do not provide the obtainment of the additional data for the improvement of cadastral valuation models, so the solution to the problem has three options (Legislation of the Republic of Latvia, Cabinet of Ministers Ordinance No. 462, 2015):

Option 1 - individual data flow and massive inspection;

Option 2 - individual data flows and data declaration under observation of State Land Service;

Option 3 - individual data flows and data declaration under observation of local municipalities.

The State Land Service offers supporting Option 2. 


\section{PRACTICAL RESEARCH ON LAND USE IN THE CONTEXT OF SUSTAINABLE DEVELOPMENT PLANNING IN LATVIA}

Environmental issues are relevant also in the framework of the efficiency of the land use. The impact of the socio-economic factors has an important role in the efficiency of the land use. And there is an interrelation between land use objectives and activities in particular sectors of national economy (Auziņš et al., 2012). For example, in China the adjusted land distribution system, which is based on the socio-economic development differences, in the future could help curb excessive cultivated land conversion, improve the land use efficiency and achieve balanced regional development (Li et al., 2015).

In many countries, also in the province of Jambi, Sumatra Island, Indonesia, socio-economic and policy factors play an important role in explaining land-use trends at the local level (Gatto et al., 2015). In case of the Zêzere water front in Portugal, waste water drainage into water courses is also a relevant concern leading to negative impacts on water quality - this fact results from a high increase in housing (urban sprawl) within superficial water body neighbourhood (Menesesetal., 2015).

Land management has a direct impact on environmental development. The running costs of the environmental protection in Latvia in 2013 are presented in Fig. 2.

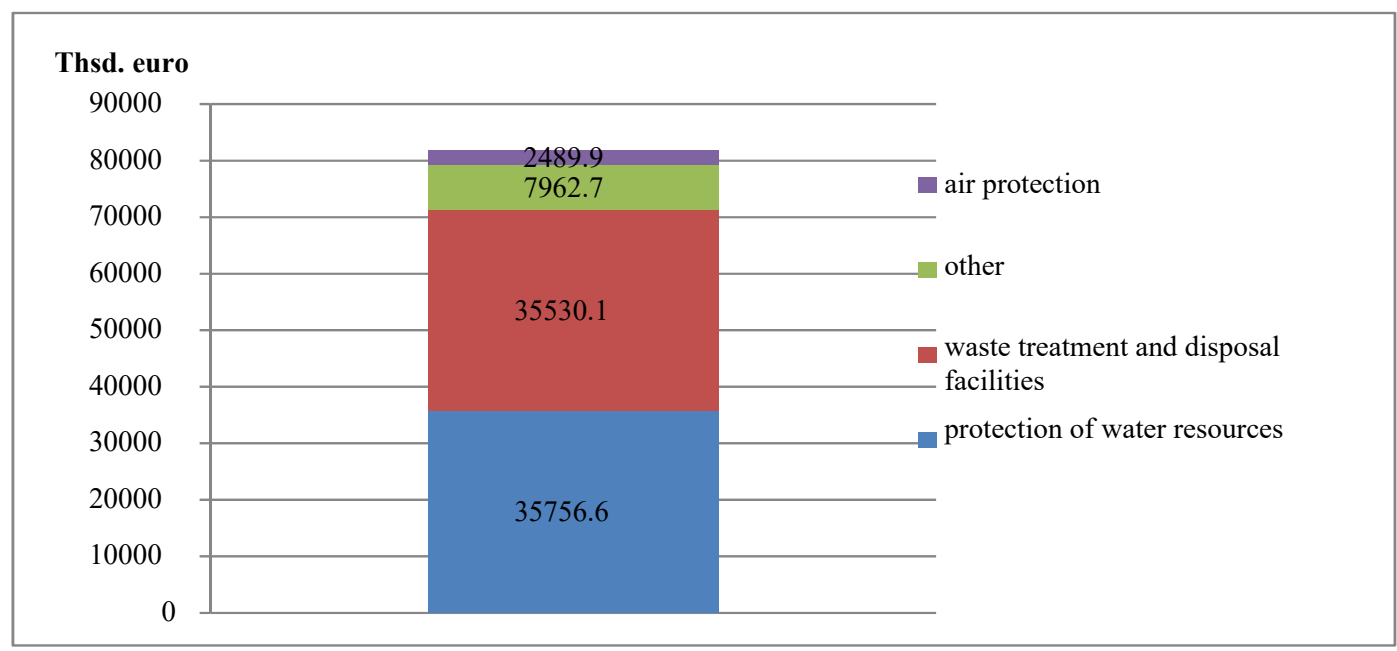

Fig. 2. Investments and current expenditure for environmental protection by environmental area in Latvia in 2013, thsd. euro (made by the authors using the Central Statistical Bureau of Latvia, 2015).

Urban control is also very important in this relation. On the example of the analysis of planning policies in the Netherlands, Belgium and Poland, it was found that dissimilar levels of urban containment could be connected with dissimilar degrees of planning adaptive efficiency (Halleuxa et al., 2015).

The urbanization process that occurs practically all over the world is of particular importance. With the development of the urbanization process, the area 
of the arable land in 2014 decreased by $26.99 \%$ in comparison with 1990 . The use of the agricultural land in Latvia is graphically presented in Fig. 3.

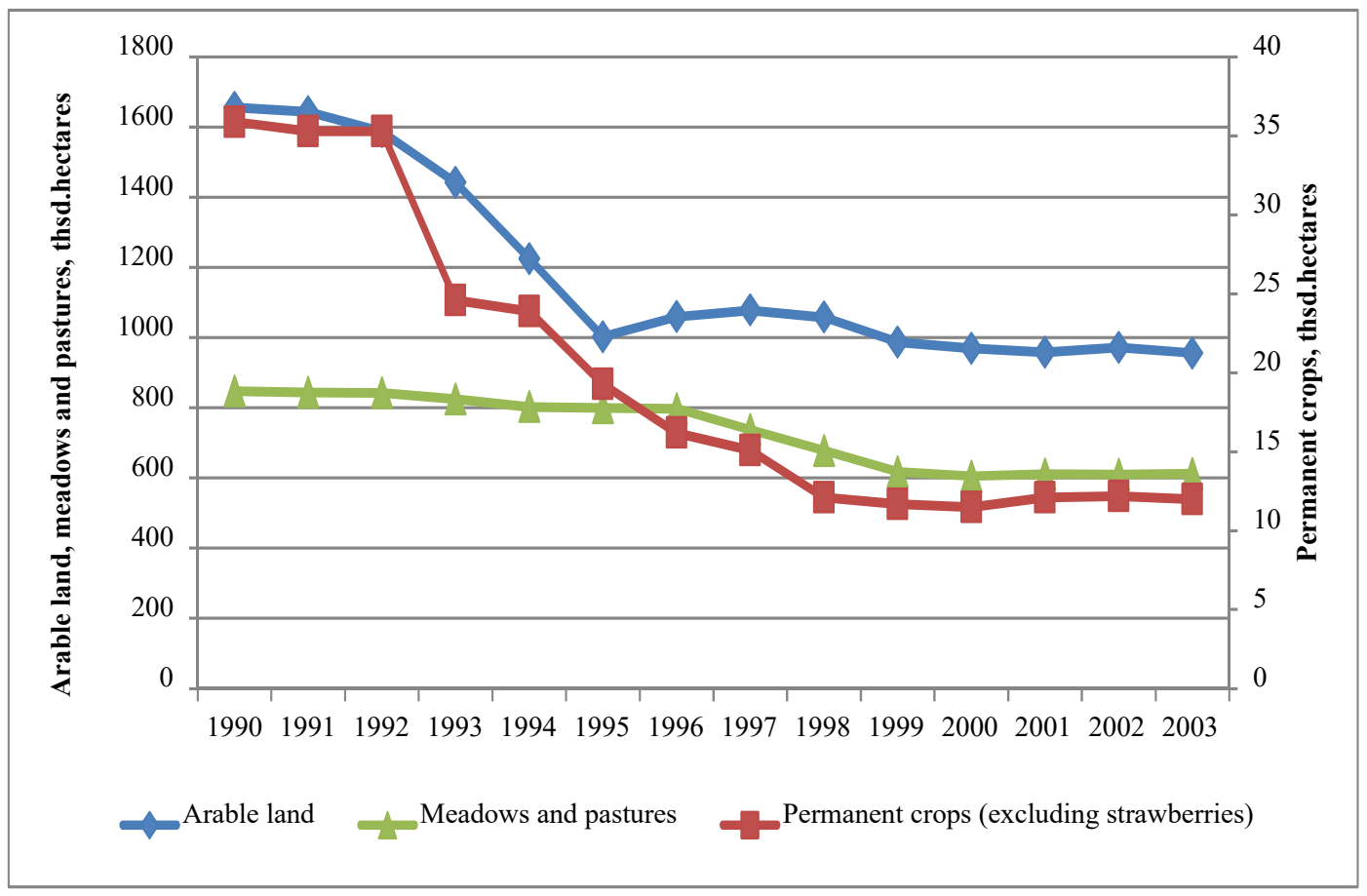

Fig. 3. Use of agricultural area (thsd. hectares) (made by the authors, using the Central Statistical Bureau of Latvia, 2015).

Nowadays, agriculture in Western and Central Europe can only achieve a high level of productivity because of a high input of fertilizers, pesticides and fodder (Möcke, 2015).

The efficiency of the land use is directly dependent on the price formation. It is important to pay attention to the following factors while assessing the value (Tepman, 2006):

- availability of different centres of gravity (objects);

- level of development of transport infrastructure;

- level of development of engineering and industrial infrastructure;

- level of development of social and public services for the population;

- environmental condition;

- historical, architectural and aesthetic value of the building, landscape and recreational value of the area;

- geological-engineering conditions and confirmation of the territory by the devastating natural and man-made impact.

Public authorities can take an active role or a passive role in the process of development of urban areas (Hartmann and Spit, 2015). Sectors that have a high added value are highly important for national economy development. Many sectors are directly and indirectly connected and are influenced by land use management, especially construction branch that also has a very high added value. Value added at factor cost in Latvia in 2013 is shown in Table 1. 
Table 1. Value Added at Factor Cost in Latvia in 2013 (thsd. euro) (NACE Rev. 2. B-N, S95; without K (Central Statistical Bureau of Latvia, 2015)

\begin{tabular}{|l|c|}
\hline Economic activity & $\begin{array}{c}\text { Value added at factor } \\
\text { cost (thsd. euro) }\end{array}$ \\
\hline (B) Mining and quarrying & 80467 \\
\hline (C) Manufacturing & 1883141 \\
\hline (D) Electricity, gas, steam and air conditioning supply & 653311 \\
\hline $\begin{array}{l}\text { (E) Water supply, sewerage, waste management and remediation } \\
\text { activities }\end{array}$ & 140625 \\
\hline (F) Construction & 831606 \\
\hline (G) Wholesale and retail trade; repair of motor vehicles & 2133751 \\
\hline (H) Transportation and storage & 1494547 \\
\hline (I) Accommodation and food service activities & 208297 \\
\hline (J) Information and communication & 693334 \\
\hline (L) Real estate activities & 637709 \\
\hline (M) Professional, scientific and technical activities & 508414 \\
\hline (N) Administrative and support service activities & 343529 \\
\hline (S95) Repair of computers and personal and household goods & 8374 \\
\hline
\end{tabular}

The same sectors that have the highest added value also create more working places, and the level of employment in these sectors is also higher (see Table 2).

So structure of national economy should be taken into account in land use management. The land can be used in several ways, which makes it difficult to determine the best and most efficient land use definition. According to Regulation of the Cabinet of Ministers No. 496 of June 20, 2006, the classification of the objectives of the use of real estate, the target groups of the use in accordance with the value constituent factors are classified into the following target classes of the use (Legislation of the Republic of Latvia, Cabinet of Ministers No. 496, 2006):

12.1. "On the land on which the buildings are not of the primary use, the building is allowed in cases where it is necessary for the permitted use". The following target groups correspond to this class:

12.1.1. 01 "Land for agriculture";

12.1.2. 02 "Forestry land and specially protected nature territory, where economic activity is forbidden with normative act";

12.1.3. 03 "Water object land";

12.1.4. 04 "Mineral deposit territories";

12.1.5. 05 "Land where the main land use is natural growth territories and land only for recreation use";

12.2. "Building land". The following target groups of the use correspond to this class:

12.2.1. 06 "Territory for construction of individual dwelling houses";

12.2.2. 07 "Territory for construction of multiple dwelling houses";

12.2.3. 08 "Land for construction of commercial objects"; 
12.2.4. 09 "Land for construction of objects for public use";

12.2.5. 10 "Land for manufacturing object building";

12.2.6. 11 "Traffic infrastructure utilization land";

12.2.7. 12 "Engineering communications object utilization land".

Table 2. The Employed by Economic Activity in Latvia in 2014 (\%). (NACE Rev. 2.) (Central Statistical Bureau of Latvia, 2015)

\begin{tabular}{|l|c|}
\hline Economic activity & \% \\
\hline (A) Agriculture, forestry and fishing & 7.5 \\
\hline (B) Mining and quarrying & 0.4 \\
\hline (C) Manufacturing & 13.4 \\
\hline (D) Electricity, gas, steam and air conditioning supply & 1.1 \\
\hline (E) Water supply; sewerage, waste management and remediation activities & 0.6 \\
\hline (F) Construction & 8.3 \\
\hline (G) Wholesale and retail trade; repair of motor vehicles and motorcycles & 15 \\
\hline (H) Transportation and storage & 9.6 \\
\hline (I) Accommodation and food service activities & 3.3 \\
\hline (J) Information and communication & 3 \\
\hline (K) Financial and insurance activities & 2 \\
\hline (L) Real estate activities & 2.3 \\
\hline (M) Professional, scientific and technical activities & 4.1 \\
\hline (N) Administrative and support service activities & 2.7 \\
\hline (O) Public administration and defence; compulsory social security & 6.6 \\
\hline (P) Education & 9.6 \\
\hline (Q) Human health and social work activities & 5.9 \\
\hline (R) Arts, entertainment and recreation & 2.5 \\
\hline (S) Other service activities & 1.7 \\
\hline Other & 0.4 \\
\hline & 3 \\
\hline
\end{tabular}

Land use regulation in the social framework affects the quality of life. The difference between urban and rural areas is also reflected in the average number of rooms per capita.

Since 2010, during the post-crisis period, in the Latvian rural area a positive trend has been observed - an increasein the average number of rooms per capita. This could also provide evidence of the population migration from rural to urban areas. In turn, during the period since 2012, this indicator in urban areas has decreased, which provided evidence of the changes inthe social factor on the negative side.

The average number of rooms in the households in the urban and rural areas is presented in Fig. 4. 


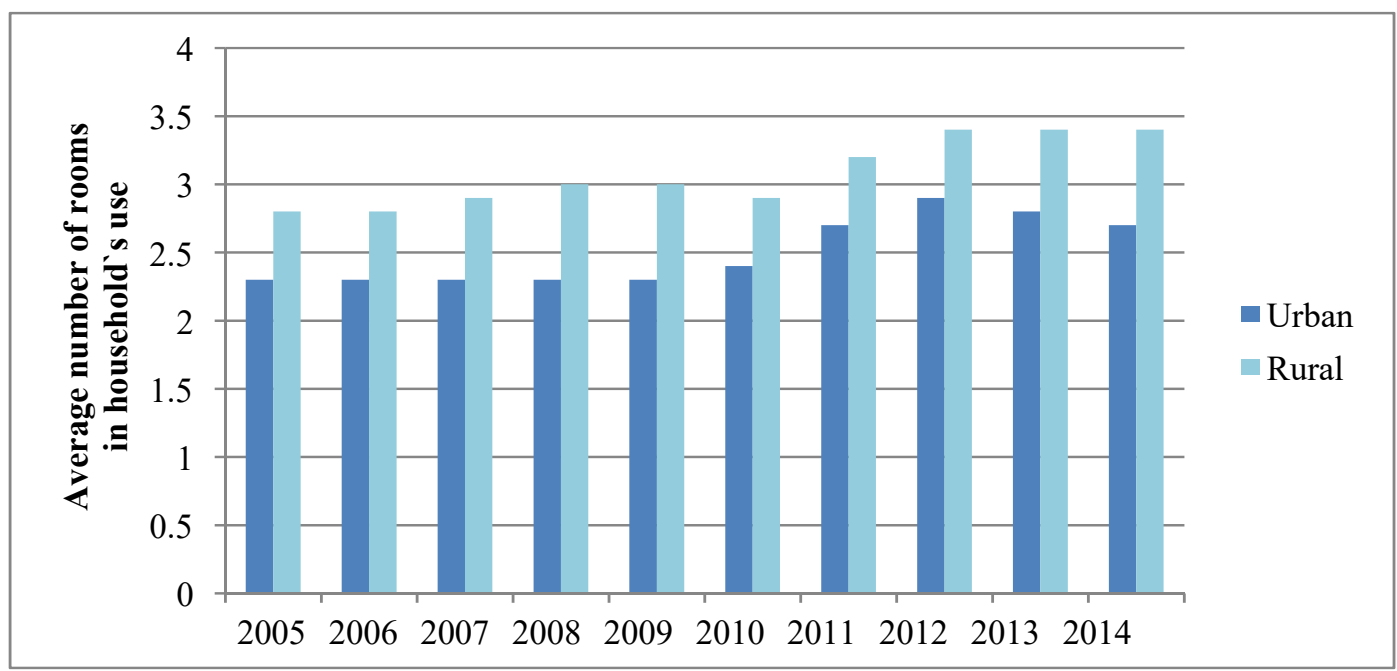

Fig. 4. Average number of rooms used by households in Latvia in urban and rural areas (made by the authors, using the Central Statistical Bureau of Latvia, 2015).

Land use planning improvements require better incentives and enforcement of regulations of market actions and private informal settlements that are largely causing risk, while encouraging more private actor responsibility for risk: the case study examples, especially in Vietnam and Nepal, where incentives are more necessary to achieve reduction of risk through land use planning (SudmeierRieuxetal, 2014). This means that the regulations should not be the only incentives for the better use of the land in land use planning.

\section{CONCLUSION}

The results of the study show that the land use analysis is a multi-step process, which requires a comprehensive approach and close attention to a number of the existing problems in the country. All the above-mentioned aspects have a direct impact on the territory and the development of the country because efficient land use can create a higher added value and increase total gross domestic product of a country.

Land use management, legal side of the regulation and the efficiency of the land use also on the part of the population are essential guidelines for the sustainable development of the territory of the country.

The following proposals are put forward for the improvement of the situation:

- the state should undertake an active role in this process in order to achieve sustainable land use management, in particular because there is an expressed inequality of the development between the Latvian regions and the capital, as well as experience of other countries can be used;

- there should be communication with the direct land owners in the course of the improvement of the efficiency of the land use and the development of the regulation base in order to strive for the best and most efficient land use throughout the country; 
Further directions of the study are related to the continuation of the practical part of the study by examining the experiences of more countries and conducting an additional qualitative and quantitative data analysis.

\section{DISCLOSURE STATEMENT}

The authors declare that they do not have any competing, financial, professional, or personal interests from other parties.

\section{REFERENCES}

Antonelli, M., Siciliano, G. Turvani, M. E., \&Rulli, M. C. (2015). Global investments in agricultural land and the role of the EU: Drivers, scope and potential impacts. Land Use Policy, 47, 98-111. http://dx.doi.org/10.1016/j.landusepol.2015.04.007 0264-8377

Auziňš, A., Grinbergs, M., \& Geipele, I. (2012). Influence of Development of Land Use Goals to the Economics of Latvia. 2nd International Conference on Applied Social Science.(ICASS 2012), Malaysia, Kuala Lumpur, 1-2 February, 2012. Los Angeles: Information Engineering Research Institute, 2012, 238-243. ISBN 9781612750064.

Bertoloa, L. S., Santos, R. F., Agar, P. M., \& Pablo, C. T. L. (2015). Land-use changes assessed by overlay or mosaic methods: Which method is best for management planning? Ecological Indicators, 55, 32-43. http://dx.doi.org/10.1016/j.ecolind.2015.03.004

Central Statistical Bureau of Latvia (2014). Statistic database. Retrieved from http://www.csb.gov.lv/dati/statistikas-datubazes-28270.html

Chakir, R., \& Gallo, J. (2013). Predicting land use allocation in France: A spatial panel data analysis. Ecological Economics, 92, 114-125.

http://dx.doi.org/10.1016/j.ecolecon.2012.04.009

European Environment Agency. (2013). Land use. Retrieved May 28, 2015. Retrieved from http://www.eea.europa.eu/lv/themes/landuse

European statistics database Eurostat. Statistics database. Retrieved from http:/ec.europa.eu/ eurostat/data/database

European statistics database Eurostat (2015, March). Land cover, Land use and Landscape. Retrieved from http://ec.europa.eu/eurostat/statistics-explained/index.php/Land_cover,_land_ use and landscape

Fischer, B., Klauer, B., \& Schiller, J. (2013). Prospects for sustainable land-use policy in Germany: Experimenting with a sustainability heuristic. Ecological Economics, 95, 213-220. http://dx.doi.org/10.1016/j.ecolecon.2013.09.006

Food and Agriculture Organization of United Nations (2015). Land use. Retrieved August, 20, 2015, from http://www.fao.org/nr/land/use/en/

Gatto, M., Wollni, M., \&Qaim, M. (2015). Oil palm boom and land-use dynamics in Indonesia: The role of policies and socioeconomic factors. Land Use Policy, 46, 292-303. http://dx.doi.org/10.1016/j.landusepol.2015.03.001

Getimis, P., Reimer, M., \& Blotevogel H. H. (2014). Conclusion. Multiple trends of continuity and change. In Spatial planning systems and practices in Europe: a comparative perspective on continuity and changes / edited by Mario Reimer et al. New York, NY: Routledge. 278-305.

Halleuxa, J.-M., Marcinczak, S., \&Krabben, E. (2012). The adaptive efficiency of land use planning measured by the control of urban sprawl. The cases of the Netherlands, Belgium and Poland. Land Use Policy, 29, 887-898. http://dx.doi.org/10.1016/j.landusepol.2012.01.008

Hartmann, T., \&Spit, T. (2015). Dilemmas of involvement in land management - Comparing an active (Dutch) and a passive (German) approach. Land Use Policy, 42, 729-737.

http://dx.doi.org/10.1016/j.landusepol.2014.10.004 
Legislation of the Republic of Latvia. Cabinet of Ministers Nr. 496. (2006). Nekustamā īpašuma lietošanas mērḳu klasifikācija un nekustamā īpašuma lietošanas mērḳu noteikšanas un maiņaskārtība [Real Estate Exploitation Purpose Classification and Real Estate Exploitation Purpose Establishment and Change Order]. Retrieved June 2, 2015, from http://likumi.lv/ doc.php?id=139503

Legislation of the Republic of Latvia. Cabinet of Ministers Ordinance Nr. 462. (2012). Par kadastrālās vērtēšanas sistēmas pilnveidošanas un kadastra datu aktualitātes nodrošināšanas koncepcija [About cadastral valuation system improvement and cadastral data freshness assurance concept]. Retrieved June 2, 2015, fromhttp://likumi.lv/doc.php?id=251895

Legislation of the Republic of Latvia (2014). Zemes pārvaldības likums [Land management Law]. Retrieved May, 25, 2015, fromhttp://likumi.lv/doc.php?id=270317

Li. Y, Li., Y., Westlund, H., \&Liu, Y. (2015). Urban-rural transformation in relation to cultivated land conversion in China: Implications for optimizing land use and balanced regional development. Land Use Policy, 47, 218-224. http://dx.doi.org/10.1016/j.landusepol.2015.04.011

Meneses, B. M., Reis, R., Vale, M. J., \&Saraiva, R. (2015). Land use and land cover changes in Zêzere watershed (Portugal) - Water quality implications. Science of the Total Environment, 527-528, 439-447. http://dx.doi.org/10.1016/j.scitotenv.2015.04.092

Ministry of Environmental Protection and Regional Development of the Republic of Latvia. (2015). Land Policy. Retrieved May 27, 2015, from http://www.varam.gov.lv/lat/darbibas veidi/tap/zem_pol/?doc $=12899$

Möcke, S. (2015). Best available techniques' as a mandatory basic standard for more sustainable agricultural land use in Europe?Land Use Policy, 47, 342-351. http://dx.doi.org/10.1016/j.landusepol.2015.04.021

O’Sullivan, L., Creamer, R. E., Fealy, R., Lanigan, G., Simo, I., Fenton, O., Carfrae, J., \&Schulte, R. P. O. (2015). Functional Land Management for managing soil functions: A case-study of the trade-off between primary productivity and carbon storage in response to the intervention of drainage systems in Ireland. Land Use Policy, 47, 42-54. http://dx.doi.org/10.1016/j.landusepol.2015.03.007

Reimer, M., Getimis, P., \& Blotevogel, H. H. (2014). Spatial planning systems and practices in Europe. A comparatative perspective. In spatial planning systems and practices in Europe: a comparatativeperspective on continuity and changes / edited by Reimer. M. et.al. New York, NY: Routledge, 1-20.

State Land Service (2015). Zemes un büvjuizmantošanasveids [Land and Building Use Type]. Retrieved May 29, 2015, from http://kadastralavertiba.lv/profesionali/vertibu-ietekmejosiefaktori/lietosanas-merkis/

Sudmeier-Rieux, K., Paleo, U. F., Garschagen, M., Estrella, M., Renaud, F. G., \& Jaboyedoff, M. (2014). Opportunities, incentives and challenges to risk sensitive land use planning: Lessons from Nepal, Spain and Vietnam. International Journal of Disaster Risk Reduction. Article in Press, Corrected Proof.http://dx.doi.org/10.1016/j.ijdrr.2014.09.009

Tepman, L. N. (2006). Оценка недвижимости: учеб. пособие для студентов вузов, обучающихся по специальности экономики и управления (2ое изд.) [Real Estate Valuation: Proc. allowance for students enrolled in the specialty of Economics and Management (2 ${ }^{\text {nd }}$ ed.) ]. Moscow: UNITY-DANA, p. 463. 


\section{AUTHORS' SHORT BIOGRAPHY}

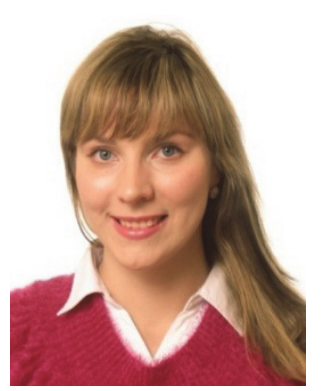

Linda Kauškale is the $\mathrm{PhD}$ student, lecturer at Riga Technical University, Faculty of Engineering Economics and Management. She has obtained the Professional Master Degree with distinction in civil construction and Real Estate Management and qualification of Real Estate Economist. She is the Head of International Real Estate Department at Ltd. AVA HOLDING. She participated in international scientific conferences: IEOM-2015 in the United Arab Emirates, International Conference on Environmental Engineering (ICEE-2014); Modern Building Materials, Structures and Techniques (MBMST-2013), Vilnius, Lithuania, etc. Research focus - real estate market analysis, influence of real estate market cycle and economic cycle on development, real estate market in national economy, sustainable environment development etc. Year 2014 - RTU Gold Fund graduate. Fall 2013 - FIABCI (International Real Estate Federation) grantee.

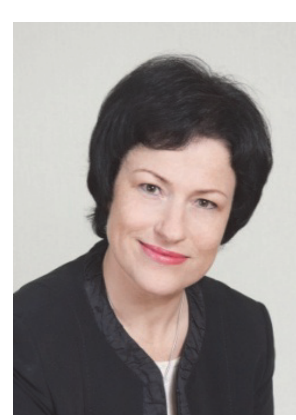

Ineta Geipele is the Professor at the Faculty of Engineering Economics and Management, the Director of the Institute of Civil Engineering and Real Estate Economics, the Head of the Chair of Civil Construction and Real Estate Economics and Management of Riga Technical University (RTU), Latvia. She has earned the Doctor's degree of Economics and Master's degree of Economics from RTU. Her professional skills are improved in Austria, Germany, Denmark and England. She is the author and co-author of more than 180 scientific publications. Her current research interests are focused on sustainability development problems of real estate market, construction industry, including land use management and institutional economics. She is an expert in management science of the Latvian Council of Science, a board member: of the FIABCI-Baltic Multinational Chapter; of the Cunfte of the Facility Management of Latvian Housing, a Member of the Latvian Union of Civil Engineers etc. 